\title{
Comment on "Soil organic stocks are systematically overestimated by misuse of the parameters bulk density and rock fragment content" by Poeplau et al. (2017)
}

\author{
Eleanor Ursula Hobley ${ }^{1}$, Brian Murphy ${ }^{2}$, and Aaron Simmons ${ }^{3}$ \\ ${ }^{1}$ Soil Science, Technical University of Munich, Weihenstephan, Germany \\ ${ }^{2}$ NSW Office of Environment and Heritage, Swan Hill, Australia \\ ${ }^{3} \mathrm{NSW}$ Dept. Primary Industries, Orange, Australia \\ Correspondence: Eleanor Ursula Hobley (nellie.hobley@wzw.tum.de)
}

Received: 30 August 2017 - Discussion started: 20 February 2018

Revised: 15 May 2018 - Accepted: 22 May 2018 - Published: 7 June 2018

Poeplau et al. (2017) recently outlined the systematic overestimation of soil organic carbon (SOC) stocks due to incorrect application of bulk density and rock fragment content in calculation of SOC stocks. Unfortunately, the method they propose to rectify this is associated with a greater error (due to assumption of rock density, extra calculation steps and propagation of errors) than the simpler mass-balance-derived equation for SOC stock calculations, outlined below. Using a mass balance approach to $\mathrm{C}$ stocks we define

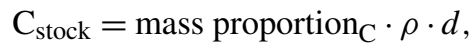

where $\mathrm{C}_{\text {stock }}$ is the amount of carbon stored in a given soil area $\left(\mathrm{kg} \mathrm{m}^{-2}\right)$ and depth, $d(\mathrm{~cm})$; mass proportion $\mathrm{C}$ is the carbon content of the whole soil $\left(\mathrm{g} \mathrm{kg}^{-1}\right)$ and $\rho$ is the bulk density of the whole soil $\left(\mathrm{g} \mathrm{cm}^{-3}\right)$.

Using a mass balance approach on the mass proportion of $\mathrm{C}$ in the whole soil, we obtain

mass proportion $_{\mathrm{C}}=\mathrm{C}_{\text {content, fine }} \cdot$ mass proportion $_{\text {fine }}$

$$
+\mathrm{C}_{\text {content, coarse }} \cdot \text { mass proportion }_{\text {coarse }} \text {, }
$$

where $\mathrm{C}_{\text {content,fine }}$ is the mass proportion of $\mathrm{C}$ in the fine soil fraction $\left(\mathrm{g} \mathrm{kg}^{-1}\right)$, mass proportion ${ }_{\text {fine }}$ is the mass proportion of the fine soil to the whole soil sample $\left(\mathrm{g} \mathrm{kg}^{-1}\right)$ and $\mathrm{C}_{\text {content, coarse }}$ is the mass proportion of $\mathrm{C}$ in the coarse soil fraction $\left(\mathrm{g} \mathrm{kg}^{-1}\right)$, and mass proportion ${ }_{\text {coarse }}$ is the mass proportion of the coarse soil to the whole soil sample $\left(\mathrm{g} \mathrm{kg}^{-1}\right)$, generally referred to as the rock content. $\mathrm{C}_{\text {content, coarse }}$ is assumed to be negligible (i.e. $=0$ ) in all methods, so the Eq. (2) simplifies to

mass proportion $_{\mathrm{C}}=\mathrm{C}_{\text {content, fine }} \cdot$ mass proportion $_{\text {fine }}$.
The mass proportion fine $_{\text {is }}$

$$
\begin{aligned}
& \text { mass proportion }_{\text {fine }}=\frac{\text { mass }_{\text {fine }}}{\text { mass }_{\text {total }}}=\frac{\text { mass }_{\text {fine }}}{\text { mass }_{\text {fine }}+\text { mass }_{\text {coarse }}} \\
& =\frac{\text { mass }_{\text {fine }}+\text { mass }_{\text {coarse }}-\text { mass }_{\text {coarse }}}{\text { mass }_{\text {fine }}+\text { mass }_{\text {coarse }}}
\end{aligned}
$$

$=1-$ mass proportion $_{\text {coarse }}$.

Substituting Eq. (6) into Eq. (3) we obtain

mass proportion $_{\mathrm{C}}=\mathrm{C}_{\text {content, fine }}$

$$
\cdot\left(1-\text { mass proportion }_{\text {coarse }}\right) \text {. }
$$

Substituting Eq. (7) into Eq. (1) we obtain

$\mathrm{C}_{\text {Stock }}=\mathrm{C}_{\text {content, fine }} \cdot(1-$ mass proportion coarse $) \cdot \rho \cdot d$.

This looks similar to Eq. (5) in Poeplau et al. (2017). However, they use the volumetric proportion, not the mass proportion of rock fragments, which is mathematically incorrect. They also state that their Eq. (6) "resembles" Eq. (8). However, their M4 is actually a more convoluted and obtuse equivalent to the commonly known and applied Eq. (8) (Ellert and Bettany, 1995; Goidts et al., 2009; Mikha et al., 2013; Orgill et al., 2013). This can be shown by combining Eqs. (3) and (6) from Poeplau et al. (2017), which illustrates that the inclusion of rock density to calculate SOC stocks is unnecessary and redundant. 
Equation (8) is also mathematically equivalent to calculations according to Eqs. (7) and (8) in Poeplau et al. (2017). However, the recommended use of the mass of fine fraction for the calculations by Poeplau et al. (2017) also has a greater potential error than using the mass proportion of rocks according to Eq. (8). The advantage of using the rock mass to correct the stocks is that rocks are (nearly) entirely conserved during sieving, whereas fine soil mass is lost as dust during sieving, increasing uncertainty in the calculations. In contrast, M4 (Eqs. 3 and 6) of Poeplau et al. (2017) requires an estimation of rock density (they recommend assuming a rock density of $2.63 \mathrm{~g} \mathrm{~cm}^{-3}$ ) to calculate the bulk density of the fine soil sample as well as to adjust for rock content. Rock density depends on parent material, with basalts having higher densities than granites, so this assumption increases error and uncertainty (Hazelton and Murphy, 2016).

Unfortunately, the additional calculations required in M4 also increase the uncertainty of the estimate due to error propagation. This can be illustrated by calculating the error terms of both equations. The squared relative error of Eq. (8) is

$$
\begin{aligned}
\frac{\sigma_{\mathrm{C}_{\text {stock }}}^{2}}{\mathrm{C}_{\text {stock }}^{2}}= & \frac{\sigma_{\mathrm{C}_{\text {content, fine }}}^{2}}{\mathrm{C}_{\text {content, fine }}^{2}}+\frac{\sigma_{\text {mass proportion }}^{2} \text { rock }}{\text { mass proportion }_{\text {rock }}^{2}} \\
& +\frac{\sigma_{\rho_{\text {sample }}}^{2}}{\rho_{\text {sample }}^{2}}+\frac{\sigma_{\text {depth }}^{2}}{\mathrm{depth}^{2}} .
\end{aligned}
$$

With mass proportion $_{\text {rock }}=\frac{\text { mass }_{\text {rock }}}{\text { mass sample }}$ and $\rho_{\text {sample }}=$ $\frac{\text { mass }_{\text {sample }}}{\text { volume }_{\text {sample }}}$ we obtain

$$
\begin{aligned}
& \frac{\sigma_{\mathrm{C}_{\text {stock }}}^{2}}{\mathrm{C}_{\text {stock }}^{2}}=\frac{\sigma_{\mathrm{C}_{\text {content, fine }}}^{2}}{\mathrm{C}_{\text {content, fine }}^{2}}+\frac{\sigma_{\text {mass rock }}^{2}}{\text { mass }_{\text {rock }}^{2}}+2 \frac{\sigma_{\text {mass }}^{2} \text { sample }}{\text { mass }_{\text {sample }}^{2}} \\
& +\frac{\sigma_{\text {volume }}^{2} \text { sample }}{\text { volume }_{\text {sample }}^{2}}+\frac{\sigma_{\text {depth }}^{2}}{\text { depth }^{2}} \text {. }
\end{aligned}
$$

The squared relative error of M4 in Poeplau et al. (2017) is

$$
\begin{aligned}
& \frac{\sigma_{\mathrm{C}_{\text {stock }}}^{2}}{\mathrm{C}_{\text {stock }}^{2}}=\frac{\sigma_{\mathrm{C}_{\text {content, fine }}^{2}}^{2}}{\mathrm{C}_{\text {content, fine }}^{2}}+\frac{\sigma_{\text {volume proportion }}^{2} \text { vock }_{\text {rolume proportion }}^{2}}{\text { rock }} \\
& +\frac{\sigma_{\rho_{\text {fine }}}^{2}}{\rho_{\text {fine }}^{2}}+\frac{\sigma_{\text {depth }}^{2}}{\text { depth }^{2}} .
\end{aligned}
$$

Using the Eq. (3) in Poeplau et al. (2017) for $\rho_{\text {fine }}$ and with volume proportion $_{\text {rock }}=\frac{\text { volume }_{\text {rock }}}{\text { volume }_{\text {sample }}}$ we obtain

$$
\begin{gathered}
=\frac{\sigma_{\mathrm{C}_{\text {content, fine }}^{2}}^{2}}{\mathrm{C}_{\text {content, fine }}^{2}}+\frac{\sigma_{\text {volume }_{\text {rock }}}^{2}}{\text { volume }_{\text {rock }}^{2}}+\frac{\sigma_{\text {volume }}^{2}}{\text { volumple }_{\text {sample }}^{2}} \\
+\frac{\sigma_{\text {mass }_{\text {sample }}}^{2}}{\text { mass }_{\text {sample }}^{2}}+\frac{\sigma_{\text {volume }_{\text {sample }}}^{2}}{\text { volume }_{\text {sample }}^{2}}+2 \frac{\sigma_{\text {mass }}^{2}}{\text { mass }_{\text {rock }}^{2}}
\end{gathered}
$$

$$
+\frac{\sigma_{\rho_{\text {rock }}}^{2}}{\rho_{\text {rock }}^{2}}+\frac{\sigma_{\text {depth }}^{2}}{\text { depth }^{2}} .
$$

With $\rho_{\text {rock }}=\frac{\text { mass }_{\text {rock }}}{\text { volume }}$ the squared relative error of M4 in Poeplau et al. (2017) is therefore

$$
\begin{aligned}
& \frac{\sigma_{\mathrm{C}_{\text {content, fine }}^{2}}^{2}}{\mathrm{C}_{\text {content, fine }}^{2}}+2 \frac{\sigma_{\text {volume }}^{2} \text { volume }_{\text {rock }}^{2}}{\text { volum }^{2}}+2 \frac{\sigma_{\text {volume }}^{2} \text { sample }}{\text { volume }_{\text {sample }}^{2}} \\
& +\frac{\sigma_{\text {mass }}^{2} \text { sample }}{\text { mass }_{\text {sample }}^{2}}+3 \frac{\sigma_{\text {mass }_{\text {rock }}}^{2}}{\text { mass }_{\text {rock }}^{2}}+\frac{\sigma_{\text {depth }}^{2}}{\text { depth }^{2}} .
\end{aligned}
$$

As can be seen, M4 has more sources of error than Eq. (8). M4 is therefore statistically inferior and should be avoided. This is in line with applying the law of parsimony (Occam's razor) to the problem of SOC stock calculations, which states that when presented with competing answers to a problem, one should choose the one which makes the fewest assumptions. Calculations according to their M4 are therefore less precise due to extra sources of error (derived from either analytical or assumed rock density as well as error propagation). As such, using Eq. (8) above, based on the C content of the fine soil, mass proportion of rocks and bulk density in the whole sample will yield the most precise estimate of $\mathrm{C}$ stocks.

With regards to eliminating the depth, $d$, from the calculations (Eq. 9 in Poeplau et al., 2017, suggested by Wendt and Hauser, 2013), it would appear that the error of this method is lower still. However, this is deceptive because the error associated with sampling a specific depth remains, so the mathematical simplification does not eliminate the error term.

Of key concern - and not addressed here - is the calculation of SOC stocks in stony soils, as here an accurate estimation of rock content is highly difficult. Estimating rock content from the profile face is highly error prone because 2D surface areas are not representative of irregular 3-D structures, such as rocks. Therefore, estimating rock content from the profile face is not volumetric. Taking larger volumes of sample in very large cores to determine the bulk density of the whole soil would help to alleviate this issue, but this would be associated with more field and laboratory work. A systematic study into this issue, similar to the systematic evaluation of sources of error when upscaling to SOC analyses to landscape stocks (Goidts et al., 2009), could help to resolve the issue.

In summary, Poeplau et al. (2017) have clearly demonstrated the need to adjust for coarse fragments $>2 \mathrm{~mm}$ in SOC stock calculations. Unfortunately, their recommendation has added some confusion to the correct method of calculation of SOC stocks via the introduction of unfamiliar formulas. Whilst mathematically correct, their formulas are associated with larger errors than the standard equation, so they present no clear advantage. As such, we recommend the use of Eq. (8) for SOC stock calculations. 
Data availability. No data sets were used in this article.

Competing interests. The authors declare that they have no conflict of interest.

Acknowledgements. EUH is funded by the Bundesministerium für Bildung und Forschung grant no. 031B0026B.

This work was supported by the German Research Foundation (DFG) and the Technische Universität München within the funding programme

Open Access Publishing.

Edited by: Bas van Wesemael

Reviewed by: two anonymous referees

\section{References}

Bispo, A., Andersen, L., Angers, D. A., Bernoux, M., Brossard, M., Cécillon, L., Comans, R. N. J., Harmsen, J., Jonassen, K., Lamé, F., Lhuillery, C., Maly, S., Martin, E., Mcelnea, A. E., Sakai, H., Watabe, Y., and Eglin, T. K.: Accounting for carbon stocks in soils and measuring GHGs emission fluxes from soils: Do we have necessary standards?, Frontiers in Environmental Science 5, 41, https://doi.org/10.3389/fenvs.2017.00041, 2017.
Ellert, B. H. and Bettany, J. R.: Calculation of organic matter and nutrients stored in soils under contrasting management regimes, Can. J. Soil Sci., 75, 529-538, 1995.

Goidts, E., van Wesemael, B., and Crucifix, M.: Magnitude and sources of uncertainty in soil organic carbon (SOC) stocks assessments at various scales, Eur. J. Soil Sci., 60, 723-739, 2009.

Hazelton, P. A. and Murphy, B. W.: "What Do All the Numbers Mean? - A Guide to the Interpretation of Soil Test Results", Third Edition, CSIRO Publishing, Melbourne, Australia, 2016.

Mikha, M. M., Benjamin, J. G., Halvorson, A. D., and Nielsen, D. C.: Soil Carbon Changes Influenced by Soil Management and Calculation Method, Open Journal of Soil Science, 3, 123-131, 2013.

Orgill, S. E., Condon, J. R., Conyers, M. K., Greene, R. S .B., Morris, S. G., and Murphy, B. W.: Sensitivity of soil carbon to management and environmental factors within Australian perennial pasture systems, Geoderma, 214/215, 70-79, 2013.

Poeplau, C., Vos, C., and Don, A.: Soil organic carbon stocks are systematically overestimated by misuse of the parameters bulk density and rock fragment content, SOIL, 3, 61-66, https://doi.org/10.5194/soil-3-61-2017, 2017.

Wendt, J. W. and Hauser, S.: An equivalent soil mass procedure for monitoring soil organic carbon in multiple soil layers, Eur. J. Soil Sci., 64, 58-65, 2013. 